\title{
Sing to Jahweh!... \\ Cursed be the day on which I was born! \\ A paradoxical harmony in Jeremiah 20:7-18
}

\author{
LC Bezaidenhout \\ University of Pretoria
}

\begin{abstract}
Sing to Jahweh!...Cursed be the day on which I was

born! A paradoxical harmony in Jeremiah 20:7-18

The paradoxical juxtaposition of the statements 'Sing to Jahweh!...Cursed be the day on which I was born!' in Jeremiah 20:13 and 20:14 creates a tension which can be avoided if these two verses are isolated from each other by way of redaction criticism. In this article, the possibility and even appropriateness of respecting the relationship between these verses is explored. The segment 7-12 is regarded as a double lament. The segments 13 and 14-18 constitute two contrasting conclusions. This segmentation coincides with time-honoured divisions of the text. Verses 7.18 can be defined as an integral unit where an ironic symphony is created by a central metaphor of procreation and counterpointed radial metaphors of sexual abuse and childbirth.
\end{abstract}

\section{INTRODUCTION}

The enigmatic character of the so-called confessions in the book of Jeremiah (11:18$12: 6 ; 15: 10-21 ; 17: 14-18 ; 18: 18-23 ; 20: 7-18)$ and their 'irregular' inclusion in the context of the book, have given rise to many interesting studies on these passages. The last of these confessions (20:7-18) is perhaps the most elusive as far as its interpretation is concerned. A survey of studies on this passage proves that no unanimous interpretation can be offered. The paradoxical juxtaposition of the statements 'Sing to Jahweh!' and 'Cursed be the day on which I was born!' in Jeremiah 20:13 and 20:14 poses an exceptional challenge to the interpreter. The juxtaposition of contrasting statements can function as a deliberate literary feature. 
The purpose of this paper is not to provide another 'exclusive, final' interpretation of the passage. It rather draws attention to another dimension of meaning that could be explored.

\section{UNITY AND DIVERSTTY IN JEREMIAH 20:7-18}

A comparative study of manuscripts proves that a process of growth underlies the text of the book of Jeremiah (cf McKane 1986:xviii-xxvii). Once this fact is appreciated, there should always be some reservation when a passage is treated as a unity. The passage could be a construction of redactors or compilers. In this case, the integrity of a passage is not warranted.

Perhaps the most risk-free approach to this passage is to accept the diversity in tone and contents as a warrant for fragmentation. Each smaller unit can be interpreted independently. McKane identifies the following segments: 7-9 'A prophet brought into contempt', 10-13 'Threatened but indomitable' and 14-18 'A curse on the day I was born (1986:467-482; cf also Baumgartner 1917:48-51, 63-67; Volz 1928:209-215; Carroll 1981:125-130; Carroll 1986:395-403). In the unit 20:10-13 verses 11, 12 and 13 do not cohere well (McKane 1986:481-482). These breaks in tone and contents are recognised by the majority of scholars. Although Rudolph (1968:130) also follows this segmentation, he accepts the possibility of regarding verses $7-18$ as a unity.

Baumgartner (1917:51) applied a form-critical method to prove the integrity of verses $10-13$. This unit resembles a typical individual lament. In this genre the sudden transition from complaint to praise is common. Baumgartner (1917:66) interpreted verses 7-9 as a connecting narrative.

Clines and Gunn (1976:390-408) used the same form-critical method to prove that 7-13 can be regarded as an individual lament. Still, verses $14-18$ are regarded as a separate unit. This approach is echoed in the studies of Diamond (1987:102) and O'Connor (1984:92-121; cf also Pohlmann 1989:33; Weiser 1959:173-182; Bright 1978:129-134).

In this paper another line of thought is followed in the interpretation of Jeremiah 20:7-18. It can be argued that the redactor of the text was a poet in his own right who constructed passages that could be analysed as integral units. Such passages could still portray tension resulting from the desire to present the original words of Jeremiah in a new composition.

It seems as if one way of segmentation has not received attention, namely that indicated by the פרעה סחומה:7-12,13,14-18; there are similarities between this segmentation and that proposed by Holladay (1986:548-551), but the basis for the 
segmentation differs. Although these segments are identified, it should not be interpreted in isolation. The radical character of the discontinuity between verses 13 and 14-18 demands consideration. Such a prominent anomaly must have been noticed by a redactor. It is improbable that a redactor, who had the freedom to arrange units within the text, would choose this arrangement in an arbitrary way and allow the different 'units' to contradict one another in the mind of the reader. It would be more feasible to regard the contrasting juxtaposition of units as deliberate literary disruption. It might be a defamiliarising device. Especially the adjacency of verses 13 and 14 must convey a strong statement by either the author or the redactor. A reconstruction of this statement will necessarily be speculative, but it can be supported by an analysis and interpretation of the text. In this paper this quest is undertaken. The interpretation is based on a form-critical evaluation of verses 7-13, a re-evaluation of the typical individual lament and its function in verses 7-18, an evaluation of different strands of meaning in verses 7-9, and the assessment of an implied meaning resulting from the proximity of verses 7-9 and 14-18 and the relationship between the metaphors employed in these units.

\section{FORM-CRIT1CAL EVALUATION OF VERSES 7-13}

Baumgartner (1917: 48-51, 63-67) drew attention to the fact that there are formal and linguistic parallels between the confessions of Jeremiah and psalms of individual lament. Elements in verses $10-13$, namely the lament (10), confession of trust $(11,12)$, petition (perhaps $12 \mathrm{~b})$ and praise (13) are typical elements in the psalms of individual lament. This comparison is meaningful in the sense that it can explain some of the curious aspects of verses 10-13, for example the sudden transition from lament (10) to praise (13) and the use of the perfect tense in verse $11 \mathrm{~b}$ (cf Psalm 6 and Psalm 22).

The proposal put forward by Clines and Gunn (1976:390-408), Diamond (1987: 102) and O'Connor (1984:101), namely that 7-9 should be included in the individual lament, does have relative merit. The form of the typical individual lament is not so rigid that it would automatically exclude the possibility of an extended lament at the beginning. Yet, in the zeal to prove the integrity of verses $7-13$, the definite distinction between 7.9 and $10-13$ is underestimated.

McKane (1986:468) duly draws attention to the fact that the occurrence of the

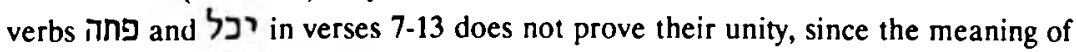
these words in verse 10 differs from that in verses 7-9. 
Verses 7-13 do comprise elements of the individual lament, but the distinction between 7-9 and 10-13 must be upheld. There are two distinct laments, one against Jahweh's vocation and one against the animosity of his opponents. Only the second complaint finds a conclusion in verses 11-13.

\section{RE-EVALUATION OF THE TYPICAL INDIVIDUAL LAMENT AND ITS FUNCTION IN VERSES 7-18}

The most popular way of explaining the sudden change in mood in the individual lament, is to infer a Heilsorakel (cf Begrich 1934:81; Gunkel \& Begrich 1933:245ff; Westermann 1981:65; Bellinger 1984:81). This interpretation might be valid with regard to the original Sitz im Leben of the individual lament, but it cannot explain all the usages of the form.

It is logical to suppose that a spiritualisation could take place as far as the Heilsorakel is concerned. During the lament, the person experiences a change in mood and expresses it in words that resemble praise after an actual deliverance (cf Gunkel \& Begrich 1933:245ff; Soggin 1976:373).

The speech in the individual lament is figurative. Type-figures and type-scenes are described that belong to the sphere of David's life and which cannot be interpreted literally as experiences of a person. It is equally improbable that the nature of God's intervention that is implied in the individual lament should always be taken literally. The individual lament could sometimes be used as a religious exercise with a therapeutic effect (with varying degrees of success).

In the book of Jeremiah, a positive divine answer is received in the first lament (11:18-23). The oracle is received after Jeremiah's affirmation of his faith in Jahweh (verse 20). In the last lament (20:7-18) the typical form of the individual lament is evident. The petition ends with words almost identical to those in 11:20. One cannot escape the impression that a deliberate comparison between these two laments has been drawn. Instead of a positive answer, as in 11:21-23, in chapter 20 it is followed by a praise (verse 13) and a self-curse (verses 14-18). There are two ways to interpret the praise. It may point to a prior or implied assurance of salvation, but this assurance satisfies only the lament in verses $10-12$ and not the lament in verses 7-9. On the other hand, it could be a typical psychological change of mood induced by the individual lament. Both interpretations can be reconciled with the negative tone in verses 14-18. On the one hand, the assurance would not be satisfactory, as the lament in verses $7-9$ is not resolved. On the other hand, an artificial generation of optimism can be short-lived and lead to depression. The comparison between $11: 18-23$ and $20: 7-13$, which is suggested by the similarity 
between 11:20 and 20:12, draws attention to the conspicuous lack of an explicit answer in 20:7-18.

It may be concluded that verses $7-12$ consist of a double lament. Verse 13 is the reaction to and conclusion of the lament in verses $10-12$ and verses $14-18$ represent the reaction to and conclusion of the lament in verses 7-9. It may be significant that the Masoretic text portrays the segments 7-12, 13, 14-18.

\section{DIFFERENT STRANDS OF MEANING IN VERSES 7-9}

The vocabulary in verses 7-9 is ambiguous. One has to agree with Baumgartner (1917:64), Rudolph (1968:130) and McKane (1986:469) that the verb פתה refers to the image of a virgin who has been seduced (cf Ex 22:16). The question arises: to what extent is the image of a seduced woman continued in this passage? According to Weiser (1959:176), Rudolph (1968:130), Berridge (1970:151), Holladay (1986: 553) and McKane (1986:470) the second verb, PII, should also be interpreted in that context, although the verb occurs only in the Hiph'il in Deuteronomy 22:25 where it refers to the forcing of a woman. On the other hand, it is possible to interpret both words without inferring the image of a seduced woman (cf Van Selms 1972:257).

Some scholars (e g Berridge 1970:153-154) suppose that this motif is continued in verse 8. The outcry רמס ושר interpreted as the expression that a woman would use in the context of indecent assault (cf Dt 22:27). The consequence of this line of reasoning would be that the scorn referred to in $7 \mathrm{~b}$ and $8 \mathrm{~b}$ should be interpreted within the context of a violated woman. Yet it is much more feasible that Jeremiah is referring directly to his actual situation (cf McKane 1986:472). At this point, decisions have to be made according to degrees of probability. If a choice must be made between the imagery of seduction and a reference to Jeremiah's actual situation, one has to conclude that the image of a seduced woman is dropped at the end of $7 \mathrm{a}$.

There still remains another line of reasoning. Is it really necessary to interpret the words in a single, exclusive way? Although the image of a violated woman ceases to figure as the primary context at the end of 7a, no explicit attempt is made to contradict the motif in the rest of the 'unit' (7-9). In fact, reference to the shame in $7 \mathrm{~b}$ and $8 \mathrm{~b}$, as well as the image of the word confined inside the body of the prophet and the prophet's inability to prevent it from coming out, can easily be associated with the motif of seduction, unwanted pregnancy and the inevitable birth of a baby. It could be possible that the author deliberately created room for different co-existing strands of meaning. The image of a seduced woman was 
strongly introduced in verse $7 \mathrm{a}$ and faded in the rest of the 'unit' (7-9). Yet, it is allowed to linger on in the imagination of the reader as a secondary motif.

The proximity of verses 14-18 also supports the validity of this interpretation.

\section{IMPLIED MEANING OF VERSES 14-18 IN THE LIGHT OF VERSES 7-9}

In these verses the metaphor of procreation, which was introduced in 7-9, is continued in another way. The image of pregnancy and birth is repeated. Even the inability to prevent birth is portrayed in a paradoxical way (verse 17). It is true that the roles are quite different in verses $14-18$, but the change in roles could have functional significance. There is a definite link between the secondary motif in verses 7-9 and the imagery in verses 14-18.

In verses 14-18 Jeremiah curses his own birth. It is obvious that he selects improbable objects for his curse. He curses the day of his birth and the person who brought his father the message of his birth. He deliberately avoids the actual source of his agony, namely Jahweh. The changing of roles is a stylistic feature. In verses 7-9 he complains against the word that he has to proclaim: a word that is associated with him (verse 8b), even part of him (verse 9). In verses 14-18 the identification of Jeremiah and the word he has to proclaim is carried further. Instead of cursing the word he has to bring forth, he curses his own birth. He is the messenger who has to proclaim the word (verse 9), but he curses the messenger who proclaimed his birth (verses 15-17). He tried to prevent the word from coming out, but it was impossible (verse 9). His main reproach in verses 14-18 is that the messenger did not prevent his birth (verse 17). The absurdity of an eternal pregnancy, referred to in verse 17 , may be assumed as a co-existing image in verse 9c. The result of his birth is toil, sorrow and shame (verse 17), aspects that are reminiscent of verses 7 and 8 .

In verses 14-18 there is a multi-dimensional irony. He apparently curses the day on which he was born and the man who brought the message of his birth, but actually he curses his own birth. The proximity of this unit to verses 7-9 introduces a new tension. Jahweh is responsible for his 'seduction' and 'undesired pregnancy'. Yet he refrains form doing the obvious, that is to curse Jahweh and his word, the true source of his agony. His identification with the word of Jahweh leads to a paradox: he curses himself instead of the word, while, at the same time, he is complaining about his suffering on behalf of the word. 


\section{CONCLUSION}

There are definite parallels between this section and Job 3, in content as well as in strategy. As in the case of Job, this co-existence of defiance and acceptance, praise and reproach, is only possible in the heart of a person who is able to contain the burning paradox of categorical commitment to Jahweh in spite of apparent selfdestruction.

\section{Works cited}

Baumgartner, W 1917. Die Klagegedichte des Jeremia. Giessen: Alfred Töpelmann. (BZAW 32.)

Begrich, J 1934. Das priesterliche Heilsorakel. ZAW 52, 81-92.

Bellinger, W H (jr) 1984. Psalmody and prophecy. Sheffield: JSOT. (JSOT Supplement Series 27.)

Berridge, J M 1970. Prophet, people and word of Jahweh: An examination of form and content in the proclamation of the prophet Jeremiah. Zurich: EVZ-Verlag. (Basel Studies of Theology 4.)

Bright, J 1978. Jeremiah: A new translation with introduction and commentary. New York: Doubleday. (The Anchor Bible.)

Carroll, R P 1981. From chaos to covenant: Uses of prophecy in the book of Jeremiah. London: SCM.

--- 1986. Jeremiah: A commentary. London: SCM. (Old Testament Library.)

Clines, D J A \& Gunn, D M 1976. Form, occasion and redaction in Jeremiah 20. ZAW 88, 390-408.

Diamond A R, 1987. The confessions of Jeremiah in context: Scenes of prophetic drama. Sheffield: JSOT. (JSOT Supplement Series 45.)

Gunkel, H \& Begrich, J 1933. Einleitung in die Psalmen: Die Gattungen der religiösen Lyrik Israels. Göttingen: Vandenhoeck.

Holladay, W L 1986. Jeremiah 1: A commentary on the book of the prophet Jeremiah chapters 1-25. Philadelphia: Fortress. (Hermeneia.)

McKane, W 1986. A critical and exegetical commentary on Jeremiah. Vol I. Edinburgh: Clark.

O'Connor, K M 1984. The confessions of Jeremiah: Their interpretation and role in chapters 1-25. Unpublished dissertation, Princeton Theological Seminary.

Pohlmann, K-F 1989. Die Ferne Gottes: Studien zum Jeremiabuch. Giessen: Alfred Töpelmann. (BZAW 179.)

Rudolph, W 1968. Jeremia. 3. Aufl. Tübingen: Mohr. (Handbuch zum Alten Testament.) 
Soggin, J A 1976. Introduction to the Old Testament. London: SCM. (Old Testament Library.)

Van Selms, A 1972. Jeremia, Deel I. Nijkerk: Callenbach. (De Prediking van het Oude Testamet.)

Volz, P 1928. Der Prophet Jeremiah. Leipzig: A. Deichertsche Verlagsbuchhandlung P. Werner Scholl. (Kommentar zum Alten Testament 10.)

Weiser, A 1959. Das Buch Jeremia. Göttingen: Vandenhoeck. (Das Alte Testament Deutsch 20/21.)

Westermann, C 1981. Praise and lament in the Psalms. Edenburgh: Clark. 